\title{
The effect of chronic ethanol administration on lipogenesis in liver and adipose tissue in the rat
}

\author{
BY CARMEN CASCALES, MANUEL BENITO, MARÍA CASCALES, \\ TRINIDAD CALDÉS AND ANGEL SANTOS-RUIZ \\ Departamento de Bioquímica, Facultad de Farmacia, Centro Coordinado del CSIC, \\ Universidad Complutense, Madrid-3, Spain
}

(Received 14 May 1982-Accepted 19 July 1983)

\begin{abstract}
1. Rates of lipogenesis de novo have been studied in liver and epididymal fat pads of male rats chronically treated with ethanol. A solution of ethanol $(150 \mathrm{ml} / \mathrm{l})$ was administered as the only drinking fluid for 3 months with a standard solid diet; both food and drink were available ad lib.

2. Lipogenesis in vivo was measured by the incorporation of tritiated water into lipid fractions: non-saponifiable lipid and fatty acids. Non-saponifiable lipid, both in liver and in adipose tissue, was unaffected by ethanol treatment. However, fatty acid synthesis de novo was significantly enhanced in both liver and adipose tissue, by 150 and $300 \%$ respectively.

3. Plasma triacylglycerol and non-esterified fatty acid levels were unchanged and plasma glucose concentration slightly increased by ethanol administration.
\end{abstract}

4. The rate of lipogenesis increased when insulin:glucagon increased twofold due to the effect of ethanol.

The accumulation of lipid in the liver following chronic ingestion of ethanol is well recognized (Lieber, 1975). Essentially four mechanisms have been postulated to account for alcoholic fatty liver. These include increased peripheral fat mobilization, decreased hepatic lipoprotein release, decreased fatty acid oxidation and enhanced hepatic lipogenesis (Lieber, 1967; Lieber et al. 1969; Lieber \& Rubin, 1969; Lieber \& De Carli, 1970).

Stimulation of hepatic fatty acid synthesis has been suggested as one mechanism for the development of fatty liver, at least when ethanol is given with a low-fat diet. The role of enhanced lipogenesis is supported by studies with rat liver slices (Lieber \& Schmidt, 1961). However, lipogenesis is highly sensitive to the integrity of cellular structures and thus the rates of fatty acid synthesis obtained in vitro with broken cell preparations are generally $10-20 \%$ of those prevailing in the intact liver (Matthes et al. 1960; Hanson \& Ballard, 1967). On the other hand, accumulation of liver triacylglycerol during the long-term administration of ethanol, seems to have no correlation with hepatic lipid synthesis (Savolainen et al. 1977) and, in acute experiments in vivo and in isolated perfused livers, ethanol has been shown to have no effect on lipid synthesis (Guynn et al. 1973; Brunengraber et al. 1974).

Considering that certain aspects of lipid metabolism have produced contradictory results, the purpose of this work was to study the effect of chronic ethanol intake on the rate of lipogenesis de novo in fed rats. Tritiated water incorporation into lipid fractions is widely used for measurements of the rate of in vivo lipogenesis. Tritium from ${ }^{3} \mathrm{H}_{2} \mathrm{O}$ is incorporated into lipid fractions not only as protons but also as tritiated NADPH generated by pathways other than the pentose phosphate shunt. Moreover, the use of tritium incorporation from ${ }^{3} \mathrm{H}_{2} \mathrm{O}$ has the advantage of adding a non-exchangeably labelled fatty acid at the last reductive step of fatty acid synthesis de novo, bypassing all other enzymic steps except those contained within the fatty acid synthetase complex. 


\section{MATERIALS AND METHODS}

Treatment of the animals

Six male Wistar rats, aged 6 months and each weighing $180-220 \mathrm{~g}$, were given ethanol solution $(150 \mathrm{ml} / \mathrm{l})$ as the only drinking fluid. Standard solid diet was supplied $(\mathrm{g} / \mathrm{kg}: 600$ carbohydrate, 35 lipid, 190 protein, 75 minerals, 10 vitamins). Feeding was maintained ad lib. for 3 months. Six control animals received the standard solid diet and water. Measurements of food and ethanol intake were carried out daily in the morning by isolating the rats in metabolism cages (Panlab SA, Barcelona, Spain). The experiments were carried out between 09.00 and 10.00 hours, the animals having free access to food and drink up to the time they were killed.

\section{Measurement of lipogenesis de novo}

At the end of the 3-month-period of intoxication the rate of lipogenesis in vivo was determined by measuring the incorporation of ${ }^{3} \mathrm{H}_{2} \mathrm{O}$ into lipid fractions from liver, blood and epididymal fat pads, as described by Lowenstein et al. (1975) and Stansbie et al. (1976). The rats were injected intraperitoneally with ${ }^{3} \mathrm{H}_{2} \mathrm{O}(5 \mathrm{mCiin} 0.5 \mathrm{ml}$; Amersham International, Amersham, Bucks) and 50 min later they were anaesthetized with Nembutal $(50 \mathrm{mg} / \mathrm{kg})$. After a further $10 \mathrm{~min}$, the abdominal cavity was opened and pairs of epididymal fat pads and samples of liver were obtained from the animals. Blood samples were drawn from the aorta. Duplicate samples were saponified with $3 \mathrm{ml}$ potassium hydroxide $(300 \mathrm{~g} / \mathrm{l})$ and fatty acids and non-saponifiable lipids were extracted and radioactivity measured. The specific radioactivity of the body water of each animal was determined by counting $50 \mu \mathrm{l}$ plasma and calculated as described by Windmueller \& Spaeth (1966). The results are expressed as $\mu \mathrm{mol}{ }^{3} \mathrm{H}_{2} \mathrm{O}$ incorporated on a per $\mathrm{g}$ wet weight and a per $\mathrm{h}$ basis. Values expressed as disintegrations/min were obtained by applying a quenching correction using an automated standardization procedure. All radioactivity measurements were carried out using a Packard TRI CARB model 2425 liquid-scintillation spectrophotometer. Evaluation of the statistical significance of the observed differences was by the paired $t$ test.

\section{Reagents}

Substrates, coenzymes and enzymes were obtained from Boehringer (Mannheim, West Germany) or Sigma Chemical Co. (St Louis, Mo., USA). Standard analytical grade laboratory reagents were purchased from Merck (Darmstadt, West Germany) and Trasylol was obtained from Bayer (West Germany).

\section{Analytical methods}

Liver and plasma triacylglycerol were determined by the method of Eggstein \& Kuhlmann (1974). Plasma non-esterified fatty acid concentration was measured according to Itaya \& Ui (1965). Blood glucose was measured in plasma using the hexokinase (EC. 2.7.1.1)glucose-6-phosphate dehydrogenase (EC. 1.1.1.49) method (Bergmeyer, 1974). Insulin was estimated by radioimmunoassay according to the method of Hales \& Randle (1963), using human insulin as the standard. Plasma samples for glucagon assay were collected using a mixture of EDTA-Trasylol ( $2 \mathrm{mg}$ sodium-EDTA + 1000 i.u. Trasylol $/ \mathrm{ml}$ blood) and its concentration was determined according to the method of Luyckx (1972) with a kit purchased from Biodata (Milan, Italy). Porcine glucagon specific for pancreatic glucagon was used as the standard. 
Table 1. Mean energy values $(k J / d)$ of food and ethanol intake and body-weight gain in rats chronically-treated with ethanol for 3 months

(Food and ethanol intakes were measured daily and the values given are the mean values with their standard errors for six experimental determinations. Weight gain was determined twice weekly and the values are the mean values with their standard errors for six rats)

\begin{tabular}{|c|c|c|c|c|c|c|c|c|c|c|}
\hline \multirow{2}{*}{$\begin{array}{c}\text { Treatment } \\
\text { group }\end{array}$} & \multicolumn{2}{|c|}{ Food } & \multicolumn{2}{|c|}{ Ethanol $\neq$} & \multicolumn{2}{|c|}{ Total } & \multicolumn{2}{|c|}{$\begin{array}{c}\text { Wt gain } \\
\text { (g/3 month) }\end{array}$} & \multicolumn{2}{|c|}{$\begin{array}{l}\text { Energy intake: } \\
\text { wt gain }\end{array}$} \\
\hline & Mean & $\mathrm{SE}$ & Mean & $\mathrm{SE}$ & Mean & $\mathrm{SE}$ & Mean & $\mathrm{SE}$ & Mean & $\mathbf{S E}$ \\
\hline Control & 314 & 26 & $\overline{c 7}$ & - & 314 & 26 & 198 & 12 & $1 \cdot 58$ & 0.12 \\
\hline Ethanol & $236^{* *}$ & $9 \cdot 6$ & 57 & $8 \cdot 4$ & 293 & 18 & $131 * * *$ & 8 & $2 \cdot 23^{* *}$ & 0.24 \\
\hline
\end{tabular}

Values were significantly different from the corresponding control values (Student's $t$ test): $* * P<0 \cdot 01$, *** $P<0.001$.

$\dagger$ Commercial standard diet contained $18270 \mathrm{~kJ} / \mathrm{kg}$.

$\ddagger$ Ethanol solution $(150 \mathrm{ml} / \mathrm{l})$ contained $4390 \mathrm{~kJ} / 1$.

Table 2. Effect of chronic ethanol ingestion on lipid synthesis in vivo in the rat (Results, expressed as $\mu \mathrm{mol}{ }^{3} \mathrm{H}_{2} \mathrm{O}$ incorporated into lipid/g wet weight per $\mathrm{h}$, are mean values with their standard errors for five to six rats per group)

\begin{tabular}{|c|c|c|c|c|c|c|c|c|c|c|c|c|}
\hline \multirow{3}{*}{$\begin{array}{l}\text { Treatment } \\
\text { group }\end{array}$} & \multicolumn{6}{|c|}{ Non-saponifiable lipid } & \multicolumn{6}{|c|}{ Fatty acid } \\
\hline & \multicolumn{2}{|c|}{ Liver } & \multicolumn{2}{|c|}{ Blood } & \multicolumn{2}{|c|}{$\begin{array}{l}\text { Adipose } \\
\text { tissue }\end{array}$} & \multicolumn{2}{|c|}{ Liver } & \multicolumn{2}{|c|}{ Blood } & \multicolumn{2}{|c|}{$\begin{array}{l}\text { Adipose } \\
\text { tissue }\end{array}$} \\
\hline & Mean & $\mathbf{S E}$ & Mean & SE & Mean & SE & Mean & SE & Mean & SE & Mean & SE \\
\hline Control & $3 \cdot 41$ & 0.9 & 1.05 & 0.2 & 0.99 & $0 \cdot 3$ & $7 \cdot 22$ & $2 \cdot 1$ & $1 \cdot 11$ & 0.4 & $2 \cdot 80$ & 0.6 \\
\hline Ethanol & 3.00 & $1 \cdot 00$ & 0.87 & $0 \cdot 2$ & $1 \cdot 15$ & $0 \cdot 3$ & $10 \cdot 92 * *$ & $2 \cdot 7$ & $1 \cdot 21$ & 0.3 & $8 \cdot 27^{* * *}$ & $2 \cdot 8$ \\
\hline
\end{tabular}

For experimental details, see p. 550 .

Values were significantly different from the corresponding control values (Student's $t$ test): ${ }^{* *} P<0 \cdot 01$, $* * * P<0.001$.

\section{RESULTS}

The mean energy intakes derived from food and ethanol are shown in Table 1. Although the mean food-energy intake was significantly lower in the ethanol-treated group, the additional energy intake as ethanol $(4390 \mathrm{~kJ} / \mathrm{l})$ resulted in the total energy intakes $(\mathrm{kJ} / \mathrm{d})$ being similar in both groups (293 ethanol group v. 314 control group). The body-weight gain $(\mathrm{g})$ during the 3-month-period for rats consuming ethanol was significantly lower than that in the control animals $(131$ v. 198; $P<0.001)$. Liver weight relative to body-weight was slightly higher $(P<0.05)$ in the ethanol-treated rats (34 (SE 3.4)) as compared with the control rats (31 (SE 3.2)).

Table 2 shows the rates of lipogenesis in vivo determined from the incorporation of ${ }^{3} \mathrm{H}_{2} \mathrm{O}$ into non-saponifiable lipid and fatty acids in several tissues (liver, epididymal fat pads and blood) in control and chronically ethanol-treated rats. Since the specific radioactivity of the body water was determined in each animal, variations in the hydration state did not affect the results. The rate of fatty acid synthesis in the liver was significantly increased $(P<0 \cdot 01)$ in ethanol-treated rats as compared with those values from controls. No changes were found in the rate of ${ }^{3} \mathrm{H}_{2} \mathrm{O}$ incorporation into the non-saponifiable lipid fraction in ethanol-treated 
Table 3. Changes in the plasma concentration of metabolites and hormones in ethanol-treated rats

(Results are the mean values with their standard errors for five to six rats per group)

\begin{tabular}{|c|c|c|c|c|c|c|c|c|c|c|c|c|}
\hline \multirow{2}{*}{$\begin{array}{l}\text { Treatment } \\
\text { group }\end{array}$} & \multicolumn{2}{|c|}{$\begin{array}{l}\text { Glucose } \\
\text { (mM) }\end{array}$} & \multicolumn{2}{|c|}{$\begin{array}{l}\text { Triacyl- } \\
\text { glycerol } \\
(\mathrm{mM})\end{array}$} & \multicolumn{2}{|c|}{$\begin{array}{c}\text { Non- } \\
\text { esterified } \\
\text { fatty acids } \\
\text { (mM) }\end{array}$} & \multicolumn{2}{|c|}{$\begin{array}{c}\text { Insulin } \\
\text { ( } \mu \text { units/ml) }\end{array}$} & \multicolumn{2}{|c|}{$\begin{array}{c}\text { Glucagon } \\
(\mathrm{pg} / \mathrm{ml})\end{array}$} & \multicolumn{2}{|c|}{$\begin{array}{l}\text { Insulin: } \\
\text { glucagon }\end{array}$} \\
\hline & Mean & SE & Mean & $\mathbf{S E}$ & Mean & $\mathbf{S E}$ & Mean & SE & Mean & $\mathbf{S E}$ & Mean & $\mathbf{S E}$ \\
\hline Control & $5 \cdot 42$ & 0.8 & $2 \cdot 21$ & 0.6 & 0.40 & 0.06 & $74 \cdot 2$ & 8 & $88 \cdot 8$ & 12 & 0.84 & 0.01 \\
\hline Ethanol & $7 \cdot 26^{*}$ & $1 \cdot 3$ & $1 \cdot 25^{* *}$ & $0 \cdot 2$ & 0.38 & 0.06 & 88.8 & 10 & $55 \cdot 0^{* * *}$ & 7 & $1.61 * * *$ & 0.8 \\
\hline
\end{tabular}

For experimental details, see p. 550.

Values were significantly different from the corresponding control values (Student's $t$ test): $P<0 \cdot 05,{ }^{* *} P<0 \cdot 01$, ${ }^{* * *} P<0.001$.

rats compared with the control rats. The rate of fatty acid synthesis in the adipose tissue of ethanol-fed rats was significantly higher $(P<0.001)$ than in the controls. The radioactivity in the non-saponifiable fraction in liver accounted for $21-31 \%$ of that which was incorporated into fatty acids. In adipose tissue the corresponding value was $12-26 \%$.

Table 3 shows the changes of plasma metabolite and hormone concentrations in ethanol-treated rats. Ethanol treatment produced a slight but significant $(P<0.05)$ increase in plasma glucose concentration. On the other hand, plasma triacylglycerol concentrations were lower $(P<0.01)$ in the treated rats as compared with the controls. There were no changes in plasma non-esterified fatty acid concentrations in either the treated or control groups of rats. Plasma insulin slightly increased and plasma glucagon decreased in ethanol-treated rats. Thus, ethanol treatment increased plasma insulin:glucagon twofold compared with control values.

\section{DISCUSSION}

The results obtained show that the concentration of plasma non-esterified fatty acids remained unaltered after chronic ethanol administration, as previously reported by Savolainen et al. (1977). However, Sameshima (1979) found that the free fatty acid concentration in the blood was lowered by ethanol; a possible explanation of those results may be enhanced esterification to neutral fat by the liver. Free access to ethanol solution $(150 \mathrm{ml} / 1)$ during a 3-month-period with a very-low-fat diet (about $50 \mathrm{~g} / \mathrm{kg}$ ) did not produce a markedly fatty liver, as can be demonstrated by the absence of changes in the hepatic triacylglycerol content (control group 171 (SE 15) mg $v$. ethanol-treated rats 145 (SE 23) mg). Moreover, the significant decrease in plasma triacylglycerol concentration can be interpreted as a consequence of an increased rate of utilization of lipid by peripheral tissues due to an increased activity of lipoprotein lipase in adipose tissue. The slight increase in plasma glucose concentration associated with ethanol treatment can be explained as follows: ethanol decreases the activity of the key enzymes of hepatic glycolysis as well as increasing the reducing power of the cell (Cascales et al. 1981).

Ethanol given $a d$ lib. as a drinking fluid during a 3-month-period, significantly activates the rate of fatty acid synthesis de novo. Although the carbon source of lipid synthesis could be reduced as a result of decreased glycolysis, acetate may be supplied directly as a product of ethanol oxidation by the liver. Thus ethanol is able to supply the two requirements for lipid synthesis (acetyl-CoA and the reducing equivalents) and the rate of hepatic lipogenesis by the effect of ethanol is enhanced in spite of diminished glucose utilization by the tissue. 
On the other hand, it is necessary to point out that the absolute values of ${ }^{3} \mathrm{H}_{2} \mathrm{O}$ incorporation into fatty acids, obtained in the present work (Table 2), are lower than those obtained by other authors (Lorenzo et al. 1981). The reason for this change may be the negative effect of age on lipogenic capacity (Fellenius et al. 1973). The present experiment was carried out with 6-month-old rats. The same age-effect can be applied to the higher rate of synthesis of non-saponifiable lipid by both liver and adipose tissue relative to that of fatty acid synthesis (Stansbie et al. 1976).

Nutritional factors have a marked influence on the rate of hepatic fatty acid synthesis, as demonstrated by the increased rate of lipogenesis in animals fed on a low-fat diet and a decreased rate in animals fed on a high-fat diet (Hill et al. 1958). Dietary carbohydrate may affect hepatic fatty acid synthesis through hormonal changes. Thus, the increase in insulin: glucagon due to ethanol treatment (Table 3) could account for the observed increase in the rate of lipogenesis in vivo as compared with that in the controls. In addition, the observed rate of lipogenesis in the liver from untreated rats contrasts with the high plasma concentration of insulin found under the same conditions (Table 3). A resistance of the liver to insulin action could be operating as a consequence of the age of the rats.

Special thanks are extended to Mrs Dolores Velasco and Erik Lundin for their assistance in the preparation of this manuscript.

\section{REFERENCES}

Bergmeyer, H. U. (1974). In Methoden der Enzymatische Analyse, pp. 1241-1246 [H. U. Bergmeyer, editor]. Weinheim: Verlag Chemie.

Brunengraber, H., Boutry, M., Lowenstein, L. \& Lowenstein, J. M. (1974). In Alcohol and Aldehyde Metabolizing Systems, pp. 329-337 [R. G. Thurman, T. Yonetani, J. R. Williamson and B. Chance, editors]. New York and London: Academic Press.

Cascales, C., Santos-Ruiz, M. R., Cascales, M. \& Santos-Ruiz, A. (1981). Ciência Biologica (Portugal) 6, $219-222$.

Eggstein, M. \& Kuhlmann, E. (1974). In Methoden der Enzymatische Analyse, pp. 1271-1278 [H. U. Bergmeyer, editor]. Weinheim: Verlag Chemie.

Fellenius, E., Nisbeth, U., Pilström, L. \& Kiessling, K. H. (1973). British Journal of Nutrition 29, $307-316$.

Guynn, R. W., Veloso, D., Harris, R. L., Lawson, J. W. R. \& Veech, R. L. (1973). Biochemical Journal 136, $639-647$.

Hales, C. N. \& Randle, P. J. (1963). Biochemical Journal 88, 137-146.

Hanson, R. W. \& Ballard, F. J. (1967). Biochemical Journal 105, 529-536.

Hill, R., Linazasoro, J. M., Chevalier, F. \& Chaicoff, I. L. (1958). Journal of Biological Chemistry 233, 305-310. Itaya, K. \& Ui, M. (1965). Journal of Lipid Research 6, 16-20.

Lieber, C. S. (1967). In Biochemical Factors of Alcoholism, pp. 167-183 [R. P. Maickel, editor]. Oxford: Pergamon Press.

Lieber, C. S. (1975). Annals of the New York Academy of Sciences 252, 24-50.

Lieber, C. S. \& De Carli, L. M. (1970). American Journal of Clinical Nutrition 23, 474-479.

Lieber, C. S. \& Rubin, E. (1969). New England Journal of Medicine 280, 705-708.

Lieber, C. S. \& Schmidt, R. (1961). Journal of Clinical Investigation 44, 1009-1021.

Lieber, C. S., Spritz, N. \& De Carli, L. M. (1969). Journal of Lipid Research 10, 283-287.

Lorenzo, M., Caldés, T., Benito, M. \& Medina, J. M. (1981). Biochemical Journal 198, 425-428.

Lowenstein, J. M., Brunengraber, H. \& Wadke, M. (1975). Methods in Enzymology 35, 279-287.

Luyckx, A. S. (1972). In Glucagon, pp. 285-298 [R. J. Lefevre and R. H. Unger, editors]. Oxford: Pergamon Press.

Matthes, K. J., Abraham, S. \& Chaicoff, I. L. (1960). Journal of Biological Chemistry 235, 2560-2568.

Sameshima, Y. (1979). Acta Medica University Kagoshima 21, 45-63.

Savolainen, M. J., Hiltunen, J. K. \& Hassinen, I. E. (1977). Biochemical Journal 164, 169-177.

Stansbie, D., Brownsey, R. W., Crettaz, M. \& Denton, R. M. (1976). Biochemical Journal 160, 413-416.

Windmueller, H. E. \& Spaeth, A. E. (1966). Journal of Biological Chemistry 241, 2891-2899. 